\title{
When the Police are the Problem: The Philippine Constabulary and the Hukbalahap Rebellion
}

\author{
Walter C. Ladwig III ${ }^{1}$ \\ DOI:10.1093/acprof:oso/9780198094883.003.0002 \\ from C. Christine Fair and Sumit Ganguly, eds., Policing \\ Insurgencies: Cops as Counterinsurgents (Oxford: Oxford \\ University Press, 2014), pp. 19-45
}

\begin{abstract}
The issue of policing lies at the heart of the Hukbalahap Rebellion (1948-1954), in large part because the indiscriminate and heavy-handed tactics employed by the country's national police force, the Philippine Constabulary (PC), was a leading factor driving support for the Huk movement. A key turning point in the campaign came with the reform and reorganization of the PC, as a result of which the bulk of the PC's personnel were transferred into the Army, which was given the lead for the COIN campaign. Although the idea of a military-led COIN campaign, with the police in a supporting role, would appear to run counter to the assumptions that inspired this volume, the example of the Philippine Constabulary illustrates the damage that an ineffectual police agency can do in counterinsurgency and the lengths that a country may have to go to ameliorate the situation.
\end{abstract}

Keywords: Philippines, Hukbalahap, police, counterinsurgency, COIN

\footnotetext{
${ }^{1}$ Department of War Studies, King's College London, London, WC2R 2LS; walter.ladwig@kcl.ac.uk.
} 
THE RESPONSE OF THE PHILIPPINE GOVERNMENT to the outbreak of the Hukbalahap, or Huk, Rebellion (1946-54) illustrates a classic pathology of weak counterinsurgent states: a fragile government attempted to forcibly suppress the outbreak of internal violence with a paramilitary police forcethe Philippine Constabulary (PC) - that lacked both the training and manpower for the task. In fact, the PC's oppressive behaviour and institutional corruption significantly increased popular support for the insurgents. Only when the need to gain access to crucial American aid compelled it to reform and restructure both its security forces and its overall strategy did the Philippine government dramatically alter its failing approach.

Not only does the experience of the $\mathrm{PC}$ highlight the problems that result from the politicization of police forces, it also raises questions about the utility of paramilitary-police style forces in counterinsurgency (COIN). Some analysts have suggested that 'indigenous police are most effective in counterinsurgency efforts when structured along paramilitary lines' (Mungie 2010: 1). They argue that such forces, charged with carrying out both police and military functions, can make a valuable contribution to both COIN and peace operations because they execute missions that would otherwise have to be undertaken by regular military forces, harming the latter's preparedness for conventional military roles 
(Havron, Chenault, Dodson, and Rambo 1969: iv, 5). Other scholars suggest that even if the decision to 'militarize' the police is not a conscious one, police forces in COIN may evolve into paramilitary forces as their roles and responsibilities are pushed beyond traditional law enforcement (Schmidl 1998: 38).

What does the experience of the PC tell us about the efficacy of paramilitary police forces in COIN? In this instance, the confused paramilitary nature of the PC, combined with the limited ability of the Philippine government to professionalize the force, rendered it poorly prepared to carry out either police or military missions. The effectiveness of the PC in COIN was only realized once it was bifurcated into a dedicated policing agency and a regular military force.

This chapter, which explores the role of the PC in the Huk Rebellion, begins with an overview of the Hukbalahap insurgents and an outline of the conflict. It then turns its attention to the Constabulary itself, with subsequent sections examining the deployment of the $\mathrm{PC}$, the political constraints on its effectiveness, and efforts to enhance its performance in COIN. This is followed by a discussion of key supporting issues, including intelligence, resources, and rule of law institutions. The chapter concludes with a discussion of the lessons this case has for future COIN operations.

\section{The Hukbalahap Rebellion}

The Hukbalahap Rebellion, which lasted from 1946 to 1954, had its roots in the agrarian unrest that had long plagued central Luzon. The largest island in the Philippine archipelago, Luzon is larger than South Korea, and home to both the capital of the Philippines and its most fertile agricultural land. In 1950, its population accounted for almost half of the country's 20 million people (CIA Report 1950: 9). At that time, nearly three-quarters of Filipinos derived their livelihood, either directly or indirectly, from agriculture; but the country's political economy was characterized by a 'feudalistic agrarian system' in which large landlords were the dominant political force (Letter, Abbey to Cowen 1951; CIA Report 1950: 3). Half of all farmers in Luzon were sharecroppers, working the estates of absentee landlords who claimed 50-70 per cent of their harvest as rent and compensation for the use of seed, work animals, and farming implements (Office of Intelligence Research 1950: iii; Crozier 1960: 38). With agricultural incomes stagnant, by the early 1940s, the supermajority of tenant-farmers was deeply indebted to their landlords. 
This highly stratified society was thrown into chaos by the Japanese invasion in December 1941 and the consequent establishment of a puppet government that employed many of the Philippine political and economic elite. The largest and most aggressive resistance group in the islands, the Hukbalahap ('People's Army against the Japanese'), consisted of tenant farmers from central Luzon and labour unions led by the Philippine Communist Party in a 'united front'. While fighting against the Japanese, the Huks (pronounced 'hooks') also set out to redress rural grievances by redistributing abandoned estates. With 10,000 full-time guerrillas and another 100,000 part-time militia members, the Huks claimed credit for killing over 25,000 of 'the enemy' -80 per cent of whom were collaborators and 'obstructionists in the class war'-and denying the Japanese access to much of the valuable rice harvest in Luzon (Memorandum, Peralta to Roxas 1946; Lachica 1971: 115; Scaff 1955: 23).

Following liberation, the Philippine government refused to recognize the Huks as legitimate anti-Japanese guerrillas - which meant they were denied compensation and benefits from the U.S. government-and replaced the officials the Huks had appointed to govern the towns and provinces under their control (Lansdale 1972: 8). As landlords began to reclaim the holdings in Luzon they had abandoned during the war, they employed 'civil guards'private militias up to 1,000 men strong - to forcibly collect back rent from tenants and eject squatters (Letter, Locket to Marshall 1948). These attempts to re-impose the pre-war social order by force were met with active resistance, as Huk fighters regrouped to defend themselves from the civil guards and defy returning landlords (Taruc 1953: 228-31).

At first the Huks attempted to achieve reform through the political system, fielding a slate of candidates from a left-wing umbrella group called the Democratic Alliance (DA) in the 1946 Congressional elections. Six DA candidates won office; however, President Manuel Roxas-a minister in the pro-Japanese government who was widely believed to have been one of the 'guiltiest of the puppets' - refused to seat the men, alleging that they had won through 'coercion, violence, threats and intimidation' (Abaya 1946: 9; Owens 1989: 194-5; Telegram 138 1949). For the Huks who fought against an occupation that claimed the lives of tens of thousands of Filipinos, the world seemed upside down. The collaborationist ruling class and the wealthy landlords who backed them were returned to positions of authority-45 members of the collaborationist government had been 
elected to Congress-while those who actually fought the Japanese were regarded with suspicion. After a prominent peasant leader died in the custody of the Constabulary, the Huks, once again turned central Luzon into a battleground (Lachica 1971: 121).

The political leadership of the Huk movement was made up of urban intellectuals from the Philippine Communist Party. With a rallying cry of 'land for the landless', they declared an intention to form a government of 'the proletariat, peasants, middle class, intellectuals, and progressive bourgeois' which would redistribute large estates and nationalize industry, as well as eject the 'American imperialists' and their military bases (Kerkvliet 1977: 224). However, analysts at the US embassy believed that the motivations of the Hukbalahap were 'essentially socio-economic, not political' (Memorandum, O'Neal 1948). Among the rank-and-file, as one former guerrilla noted, the prime reason for fighting was to stop 'the civilian guards and PC from beating up my family' and see that 'the DA congressmen hold office' (Kerkvliet 1977: 164).

Organized into 100-man squadrons, Huk bands operated at will across central Luzon in formations as large as battalion-size (1,200). Exploiting surrounding swamps and mountains as base areas, they attacked civil guards and ambushed constabulary patrols, hijacked commercial trucking, and robbed provincial treasuries, compelling the government to disperse its limited forces to defend large areas of the countryside (Cable 1986: 50; Kerkvliet 1977: 205, Scaff 1955: 28; Telegram 311 1949). As one scholar assessed-'in numbers, organization and small arms the Huk fighting units were comparable to the government forces. In terms of morale and civilian support in the areas of their operations, they had a decided advantage' (Scaff 1955: 28).

The reach and power of the insurgents was shockingly illustrated in April 1949 when several squadrons of Huks ambushed a motorcade containing the widow of Manuel Quezon, the country's beloved wartime president-in-exile, her daughter and son-in-law, the head of the Army Intelligence, and the Mayor of the capital (Quezon City), killing them all (Telegram 1126 1949). Large swaths of Luzon, including 6,000 square miles of the richest rice growing region in the country, were soon being referred to as 'Huklandia' in recognition of the insurgents' domination. Independent assessments found that 'about half the people in dissident-infested areas are pro-Huk', and information the insurgents received from a sympathetic public and agents within the Philippine government frustrated 
the government's efforts to hunt them down (Telegram 561 1949; Telegram 458 1950; ‘AFP Brief for Melby Mission’ 1950; JUSMAG 1951).

Following widespread fraud in the 1949 presidential election-perpetrated on behalf of the ruling Liberal Party by the PC - the insurgents' ranks swelled, peaking at an estimated 15,000 guerrillas under arms at any one time (drawn from a pool of 30,000-50,000 part-time fighters), 100,000-strong clandestine political organization, and nearly two million active sympathizers (Bohannan 1962: 21; Kerkvliet 1977: 155; Taruc 1967: 60; Telegram 578 1950; Telegram 458 1950). The frequency of Huk attacks increased tenfold, and soon they were conducting near daily raids on army posts and spreading their operations into outlying districts of Manila (Greenberg 1987: 65). By April 1950, an estimated 500,000 Filipinos had fled or been displaced by the fighting (Memo, Perez to Quirino 1950). The security situation in the country was so precarious that armoured cars were deployed near key government buildings in the capital, while the country's president took to sleeping on his yacht lest he need to make a quick escape (Lansdale 1971; Telegram 2694 1949). Fearful for their safety, those local government officials who had not been co-opted by the Huks refused to remain in central Luzon after nightfall and would return daily to the relative safety of Manila-thus further weakening the link between the government and the governed.

However, following the rise of a new reform-minded Secretary of National Defence, Ramon Magsaysay, government security forces were reorganized in a manner that enhanced their COIN prowess and reduced the abuses of the civilian population which were driving support for the insurgency. In 1951, revitalized government forces were killing Huks at the rate of 40 to 50 a week (Lachica 1971: 131). By the start of 1952, the estimate of the number of guerrillas in the field had fallen from 15,000 to 8,000, and the U.S. embassy was reporting that the 'dissident problem [had been] reduced from a military threat...to nuisance raids' (Telegram 2318 1952). Increasingly cut off from the population and lacking both supplies and solid intelligence, the insurgents were soon spending more time and energy evading the government forces than planning offensives. Although it was not entirely safe to travel anywhere outside Manila after dark, by early 1953, the insurgency was believed to be in a state of 'continued deterioration' having been 'winnowed down to diehards' (Telegram 1794 1952; Telegram 2200 1953). 


\section{Deployment of the Security Forces}

At the start of the insurgency, internal security in the Philippines was provided by the Philippine Constabulary, a 24,000-man paramilitary police force. As a national police force, the PC's remit was to respond to large-scale disturbances such as riots and insurgency as well as maintain order in remote areas where local police forces were non-existent. Organized into 100man companies, the PC was deployed across each of the country's 50 provinces, with a Constabulary Provincial Commander overseeing one or more companies in each province. When large-scale operations required it, these companies could merge into battalion-size formations; however, to provide effective police coverage, companies were more frequently subdivided into detachments of 5-50 men scattered in penny-packets throughout a province, often in isolated or far-flung areas. In much of the archipelago, the PC was the most visible symbol of law and order. It was also the government institution with the most conspicuous presence and constant contact with the population, which meant that its actions had a disproportionate ability to shape popular perceptions of the government.

As a result of its remit and deployment patterns, the $\mathrm{PC}$ was the first responder in cases of internal violence, such as the Huk Rebellion. Luzon had a long history of agrarian unrest and the government initially believed that Huk violence was merely small-scale banditry. From 1946-8, the Huks were largely dealt with as a routine law and order issue, with no concentrated attention given to the problem. The PC established check-points on major highways in Huk-affected areas, but this practice had no appreciable military utility since 'out of inertia and lack of imagination' the screening operations were conducted at fixed locations, and were thus easy for the Huk to avoid (Valeriano and Bohannan 1962: 134). The Constabulary occasionally searched villages believed to be hiding insurgents; however, the majority of its time was spent on garrison duty.

By 1948, the Huks had expanded the scope of their operations to the point where President Roxas declared them an illegal organization seeking to overthrow the government (Despatch 366 1948). Insisting that 'the only way to fight force is to meet it with superior force', he dispatched the PC to actively suppress the Huks in a 'mailed fist' campaign, with 'extermination through military action...the basic aim' (quoted in Manila Chronicle 1948; Scaff 1955: 28). These operations were, at best, inconclusive-the government did manage to kill, capture, 
or suppress roughly half the guerrilla fighters in the Huk army, but not only were those losses replaced, the insurgents expanded by a further 3,000 fighters. The central government lacked interest in the conflict and failed to provide sufficient resources to undertake operations. With little to show for their operations, the security forces' morale plummeted. Units adopted a defensive mentality and merely went through the motions of attempting to root out the insurgents. Some constabulary units purposefully patrolled areas known to have no insurgent presence to avoid combat, while government officials in Huk-dominated areas paid off the insurgents to avoid becoming the latest victim of their assassination campaign (Airpouch 814 1950).

In mid-1950, the Philippine government reoriented its strategy, splitting the constabulary into dedicated police and military agencies, and giving the army the lead role in COIN. In conjunction with a series of reforms that reorganized and revitalized the Philippine armed forces, this new army-led approach put military pressure on the insurgents while actively seeking to ameliorate the major grievances driving support for their cause.

\section{Political Effects}

The PC was largely organized according to the continental model of policing, whereby the paramilitary force was the strong arm of the executive branch, highly centralized and focused on crime suppression in order to protect the state, rather than the citizenry. As a nation-wide force under the command of the executive branch, the constabulary was primed for politicization. Indeed, the head of the PC was appointed by the President-subject to confirmation by Congress - and served at the president's pleasure with no defined term of office.

The Constabulary Commander, Brigadier Alberto Ramos, was a collaborationist accused of having personally overseen the execution of American and Filipino guerillas on behalf of the Japanese. The US embassy in Manila reported that Ramos, who was also alleged to have previously been involved in illegal arms trafficking, 'does not appear to be well qualified' for his job (Airgram A-160 1949; Letter, Chapin to Gullion 1950). However, his personal loyalty to the President secured his position. Under Ramos, the constabulary was a tool of the ruling Liberal Party, used to falsify electoral registers, shutdown local newspapers, and 
attack opposition candidates and their supporters. Administratively, the constabulary was under the control of the Ministry of the Interior, which largely served to advance the interests of large landlords vis-à-vis agricultural workers. Indeed, the Minister of the Interior himself was described by the U.S. Embassy as a 'reactionary member [of the] landed gentry' (Telegram 1862 1948).

At the sub-national level, provincial governors were charged with maintaining peace and order in the cities and towns they oversaw. Thus, constabulary companies and their commanders were subject to local political influence as well. Though theoretically independent of the provincial governor or local congressman, constabulary units often did the bidding of these politicians, including collecting intelligence on political opponents (Memorandum, Samaon Afdal to Chief of Constabulary 1949). Company commanders who did not cooperate with local politicians or were unwilling to overlook infractions of the law by the politically well-connected often found themselves transferred or relieved of duty. Detachments that were supposed to be protecting major population centres were frequently redeployed to guard the estates of politically influential landed interests, which left towns and villages vulnerable to infiltration by the insurgents. The politicization of the constabulary further eroded its professionalism as the leadership of the force was stocked with political loyalists rather than competent officers. Instead of accurately reporting the situation, these officers repeatedly told authorities in Manila that the Huks were being defeated in the field and that 'ultimate victory was in sight' (Smith 1958: 145-6).

Reform and restructuring of the constabulary-in particular moving it from the Ministry of the Interior to the Ministry of National Defence-depoliticized the force, which enhanced its COIN prowess, albeit at the cost of the Liberal Party's control. Free and fair elections held in 1951 gave as important a boost to the prospects for peaceful democratic change as the fraudulent 1949 elections had given the Huks. But those on the losing end of the reforms were not pleased with the change. After the Liberals suffered a significant defeat in the 1951 Congressional elections-largely due to their inability to use the constabulary to intimidate opposition candidates-several prominent party leaders, including the Speaker of the House, attempted to undo the reforms that had weakened their hold on power. In the run-up to the 1953 presidential election, the Liberals attempted to remove the constabulary from the authority of the 
steadfastly non-partisan Secretary of National Defence (Manila Chronicle 1951; Telegram 2000 1951; Airpouch 339 1952). It required the direct intervention of the US-which threatened to immediately cut off military aid if the constabulary were transferred back to the control of the Ministry of the Interior-for the Liberals to retreat from their attempts to undo these critical reforms (Telegram 1953 1953).

\section{Enhancing Police Efficacy}

As a paramilitary police force, the PC was supposed to be trained to perform both military and policing duties; however, the force rarely excelled at either task. The Philippine economy had been shattered by World War II and the government did not invest sufficient funds to develop the PC into a highcalibre force. The Constabulary School at Camp Crane in Rizal Province offered a 10-week Criminal Investigation Course, but limited training funds and the deteriorating internal security situation meant that very few personnel could actually attend (Department of the Army 1952: 5). Smallunit training for military operations, based on US infantry tactics, was supposed to take place at the company level; however, this on-the-job training was frequently disrupted by the fragmented deployment of individual platoons and squads across a company's area of responsibility.

In 1949, the deteriorating security situation led the Philippine government to appeal for emergency American military aid. While the State Department believed that the Philippine government could not bring the Huks under control without significant financial assistance, the American ambassador in Manila, Myron Cowen, was concerned that unconditional grants would further encourage the Philippine government to use repression to solve its problems (Memo, Ely to Allison 1949). Since the actions of the PC were widely regarded as a key driver of support for the insurgency, augmenting its capacity without also altering its behaviour could be extremely counterproductive (Airpouch 307 1950).

Recognizing that abuse by the security forces was driving support for the Huks, in mid-1950, the commander of the Joint US Military Assistance Group (JUSMAG) warned Roxas' successor, President Elpidio Quirino, that the 'Constabulary, combined with the vicious system of Civil Guards, has gotten seriously out of hand during the past year' (Letter, Anderson to Quirino 1950). JUSMAG's solution 
was to shift responsibility for the COIN campaign to the non-partisan and more professional 13,000-man army, which would then be quickly expanded by consolidating the constabulary under the command of the Ministry of National Defence. Not only would this move enhance the coordination of COIN operations by bringing all of the security forces under a single command, it would also allow US military aid, which could not be used for police forces, to benefit the constabulary. Although the Philippine Secretaries of the Interior and National Defence expressed their opposition to such a move on the grounds that blurring the lines between policing and warfighting 'would be dangerous', JUSMAG observers believed that they really objected to the fact that integration into the military chain of command would put the constabulary beyond the influence of local politicians who frequently used it for their own ends (Memorandum, Baluyut to Quirino 1949; JUSMAG 1949: 4 November, 8 December). This was, of course, precisely what the JUSMAG intended.

The Embassy and the JUSMAG made it clear that American military assistance was conditioned on the integration of the PC into the army (Abueva 1971: 146). In the face of this pressure, Quirino tried to secure the aid by bluffing his patrons. He agreed to cap the constabulary at 12,000 men, with the rest of the force integrated into the army; but he avoided implementing the measure for six months (JUSMAG 1949: 22 December). During this time, he tried to place pressure on the United States by openly criticizing the Truman administration's failure to assist the Philippines (Telegram 674 1950: 1418; Abueva 1971: 147). The United States stuck to its guns, however, and held back additional military aid until the PC was restructured.

In late March 1950, on the anniversary of their founding, the Huks launched large-scale coordinated attacks across Luzon which put Philippine forces on the defensive. Despite the increased insurgent threat, US military assistance remained contingent on the reorganization of the constabulary and the implementation of concrete reforms to reduce abusive treatment of the civilian population. President Quirino, who was under considerable pressure, finally relented, signing an order that reduced the PC to 7,000 men, transferred 17,000 PC personnel to the army, and placed the PC under the operational control of the Department of National Defence (Telegram 211 1950; Telegram 220 1950; JUSMAG 1950). The Philippine Armed Forces now consisted of four branches - the Army, the Air Force, the Navy, and the PC. 
This reorganization was closely followed by the emergence of energetic and reform-minded leadership at the Department of National Defence. After a major Huk offensive saw the insurgents attack a dozen towns across Luzon, temporarily capture two provincial capitals, and overrun a constabulary base-where they massacred the nurses, patients, and doctors in the facility's hospital before burning it down-frustration boiled over in the Philippine government. When the Secretary of National Defence resigned, the US embassy pushed for the appointment of Ramon Magsaysay, a Liberal Party congressman and Chairman of the House National Defence Committee, as Secretary of Defence. During the Japanese occupation, Magsaysay had fought with a pro-American guerrilla unit and shared the views of many in the U.S. Embassy and JUSMAG regarding the need for reorganization of the Philippine armed forces (Abueva 1971: 147-8).

Once in office, Magsaysay proved to be a tireless and capable leader who set out to transform the armed forces. He sought to reenergize the military, raising their morale while simultaneously building public confidence in the force. Magsaysay worked to eliminate a major cause of support for the insurgents by curtailing the armed forces' mistreatment of the civilian population. He empowered vigorous young field commanders to operate in the Huks' 'liberated zones', denying them access to food and supplies. He also depoliticized the military by cashiering cronies and reducing corruption, while simultaneously augmenting training for regular soldiers to increase their capacity and professionalism (Hart 1953: 67). Higher pay and greater logistical support for units in the field improved discipline and eliminated the need for soldiers to steal from the population or scavenge supplies when on patrol (Letter, Jones to Quirino 1948; Greenberg 1987: 85; Valeriano and Bohannan 1962: 2081). American military and economic aid facilitated Magsaysay's efforts, allowing him to raise the salaries of Armed Forces of the Philippines (AFP) personnel and undertake civic action projects in rural areas.

Following the force's consolidation and incorporation into the Department of National Defence (DND), the remaining elements of the PC were reorganized for the enforcement of law and order (Department of the Army 1952: 2). Although the company remained the PC's basic unit, the size of these formations was shrunk by a third. With the army taking the lead in COIN, the primary contribution of the re-structured constabulary was to prevent organized lawlessness in rural areas, which 
might otherwise divert army resources from anti-Huk operations. The constabulary primarily facilitated COIN operations by providing units with intelligence on specific people and developments in their area of responsibility and in some instances eliciting public support for army operations. However, in the case of a Huk raid on a population centre, PC units would attempt to engage the insurgents until the army could arrive.

The problem of training continued to plague the PC. With the army taking the lead against the Huks, it took priority when it came to limited training funds. Between January 1950 and June 1952, just 270 officers and 450 men (10 per cent of the force) completed the training course at the Constabulary School (Department of the Army: 6). Moreover, the continual demands of police operations undercut the opportunities for unit training. The Philippine government drew up plans 'for bringing all Constabulary companies from the field for eight weeks of training in basic and technical subjects...' but the requirements of on-going policing meant that throughput averaged only 12 per cent of the force per year (Department of the Army: 6).

With the constabulary free from the politicized influence of the Ministry of Interior, Magsaysay was able to court martial 'weak, inefficient and corrupt officers and enlisted personnel', resulting in the cashiering of over 400 unfit officers in the subsequent three years, including the Constabulary Commander Brigadier Ramos (Department of the Army: 5; Hart 1953: 67; Lansdale 1972: 43). Since the constabulary and the army were both under the DND, movement of personnel between the two organizations was quite frequent. Unfortunately for the PC, the government's policy of reassigning energetic and capable constabulary officers to the army meant that the organization continued to suffer from a shortage of competent leadership. Nevertheless, under the DND's strict oversight, the constabulary was free of the political influence that had previously tainted its operations. In combination with an aggressive effort to dismiss incompetent and corrupt personnel, the PC began to shed its abominable reputation (Department of the Army: 5).

Meanwhile, the elements of the constabulary merged into the army were organized into 1200-man Battalion Combat Teams (BCT)—reinforced infantry battalions complete with reconnaissance assets. It was envisioned that the BCTs, as mobile, combined-arms forces, would be capable of independent operations in the rough terrain of Luzon while having more mobility and flexibility than the PC companies they 
replaced. Moreover, these larger-sized formations would better deter Huk ambushes. In early 1950, the Philippine army had just two combat-ready infantry battalions, but by the end of the year it had 10 operational BCTs, many of them formed from former constabulary companies. To professionalize the force, army officers were assigned to command former PC companies, who received modern weapons and advanced unit training.

\section{Police Performance in the Fight}

In the early years of the Huk Rebellion, poorly paid and trained enlisted members of the constabulary contributed to the government's problems through the 'irregularities of [their] conduct—one time too vicious in their conduct, another time, so lax as to intermarry with Huk women' (Telegram 1152 1950). Low-and frequently delayed-pay meant that the PC had to loot supplies from the local peasantry. Road checkpoints, supposedly established to reduce the insurgents' freedom of movement, became opportunities for the members of the PC to collect 'tolls' to supplement their wages (Valeriano and Bohannan 1962: 79). The US embassy estimated that there was a 'fineness of demarcation' between the Huks and the constabulary. 'All have guns... and all are completely irresponsible' (Telegram 1152 1950). At the same time, constabulary officers were accused of enriching themselves by levying illegal taxes on plantations and forcing farmers to thresh their rice in constabularyrun mills (Melby Mission 1950). Not only did these practices create widespread corruption among the PC, they harmed the government's relations with the local population.

With the majority of constabulary elements tied down in static protection duties, the PC rarely took offensive action against the Huks unless compelled to do so by high-level political pressure or 'scathing newspaper comments' (Valeriano and Bohannan 1962: 94). In offensive operations, employing the conventional tactics of positional war, the constabulary repeatedly attempted to encircle the highly mobile Huks and bring them to battle, which proved to be as ineffective as it was destructive (Telegram 1011 1950; Telegram 492 1949). In the absence of a clear campaign plan or centralized command mechanisms, PC companies conducted operations as the local commander saw fit. Without effective intelligence, the PC relied on indiscriminate measures to separate the guerrillas from the population-large scale cordonand-search operations, 
food denials, and collective punishment. The latter included the slaughter of livestock, the destruction of crops in the field, the demolition of dwellings, mass arrests, and summary execution of hundreds of peasants (Moore 1971: 11). It is not without justification that some scholars judged that the PC conducted itself 'like an army of occupation' (Greenberg 1987: 70; Lachica 1971: 121).

As Huk political leader Jesus Lava readily admitted-'The great majority of Huks joined because of repression by the Philippine Government... and civilian guards. Many felt it was either join or be killed without at least putting up a fight'. The US embassy concurred, noting it was 'reasonable to assume that some of the Huks are merely trying to avenge mistreatment at the hands of the PC' (Telegram 1152 1950). Embassy personnel advised Washington that-'so long as the constabulary seize foodstuffs without paying for them, become drunk and disorderly, extract information by inhumane methods, abuse women, shoot up country towns and generally mistreat the populace, just so long they will continue to lose the Philippines to the [Huks]' (Despatch 432 1950: 1436).

Following the reorganization of the security forces and the designation of the army as the lead COIN force, the situation changed markedly. Central Luzon was blanketed with battalion combat teams, many in areas that had formerly been Huk 'safe zones' (Kerkvliet 1977: 208). Each BCT was assigned a specific zone of operations - typically half or a third of a province. Initial deployments tied down the majority of the BCTs in static defensive positions as they focused on protecting the population against Huk raids and generating the local intelligence necessary for offensive operations against the insurgents. Army BCTs began by establishing a presence in the major barrios in their area of responsibility, where they disrupted the link between the active guerrillas and their supporters by establishing roadblocks and enforcing curfews.

The conspicuous large-scale sweep operations were replaced by small formations which penetrated deeply into Huklandia in search of the insurgents' base areas (Kerkvliet 1977: 241). Not only had it been relatively easy for the highly mobile insurgents to avoid the large-scale operations, it was frequently during sweep operations that the security forces, unable to corner their elusive prey, vented their frustrations on the civilian population. Previously, the Filipino security forces had only conducted desultory patrols along major roads adjacent to their cantonments. Under Magsaysay, the security forces focused on off-road 
patrolling by squadron or platoon sized units, conducted on an irregular basis and often lasting several days at a time.

To demonstrate that the government could be a force for good, the constabulary and other elements of the armed forces undertook 'civic action'-digging wells in remote areas, repairing roads and bridges, providing basic medical treatment to rural peasants, and building schools. With American aid, 300 miles of new roads were laid and over 2,000 wells were dug across the island over the subsequent four years (Greenberg 1987: 139). Government lawyers were ordered to assist citizens in pursuing legal action against abusive military personnel and represent tenant farmers in their legal disputes with landlords for free (Telegram 1194 1951: 1510-11; Lansdale 1972: 48). To ensure that the security forces were accountable, the Defence Secretary established a nickel telegram service that would allow any Filipino to send a message reporting any abuse or problems directly to his office.

Having fought as a guerrilla against the Japanese, Magsaysay knew how hard the life of an insurgent can be. To provide rank-and-file Huks a way to give up their struggle, he established an amnesty that allowed those who were not guilty of a major crime to reintegrate into society. Surrendered guerrillas were given the tantalizing option of joining the Economic Development Corps (EDCOR), which used American aid to create reintegration settlements on other less populated islands (Romulo and Gray 1957: 167, 221). EDCOR offered the opportunity to establish a 20-acre homestead on the island of Mindanao, with the government helping him to clear land, build a home, and purchase supplies. Retired soldiers and their families lived alongside selected former insurgents and kept watch over their formerly wayward fellow citizens. If the Huk worked his plot of land for several years, he was granted the title in perpetuity.

Only 950 families were ever resettled by EDCOR—less than 250 of whom were those of former guerrillas (Kerkvliet 1977: 239). However, the effort directly responded to the Huks' slogan of 'land for the landless'. News that the government was providing land to surrendered insurgents triggered a wave of defections. Why fight for a farm and a future when the government was giving it away? The Philippine government estimated 1,500 active guerillas surrendered to try to join the EDCOR programme, which would have otherwise tied up several thousand additional government troops had they remained in the field. 
By early 1951, Ambassador Cowen was reporting back to Washington that the reforms were 'injecting new enthusiasm in [the] armed forces which may be [the] dominant factor in improving effectiveness' (Telegram 2157 1951). This view was corroborated by Huk leader Jesus Lava, who said that 'when Magsaysay started making reforms in the Philippine army and in the government generally it had an impact not only on the movement's mass support but on the [guerrillas] as well' (Kerkvliet 1977: 238). In the second half of 1951, the new leadership of the AFP and the reforms instituted by Magsaysay began to have an impact as the new BCTs successfully undertook offensive operations against the insurgents. With morale on the rise, the armed forces were displaying increasing levels of competence. The reorganized BCTs slowed the Huks' progress and began to place the insurgents on the defensive, forcing them to abandon Luzon's fertile agricultural plains for the sanctuary of the island's mountains and swamps.

\section{Intelligence}

In the early years of the conflict, the PC's predatory treatment of the civilian population hindered its ability to cultivate intelligence from the populace. Moreover, according to JUSMAG assessments, the Philippine government's capacity to develop raw information into actionable intelligence and disseminate it in a timely manner was 'extremely poor' (JUSMAG Brief for Melby Mission 1950). Until the end of 1951, the government's intelligence efforts had been fragmented, with the PC, the Military Intelligence Service (MIS), the National Bureau of Investigation, the Manila Police Department, and a host of other agencies all independently collecting intelligence on the Huks (Valeriano and Bohannan 1962: 138). Although these agencies did a reasonable job of pushing intelligence up to the country's national leadership, there was little downward transmission of actionable information to units in the field, nor was intelligence sharing across agencies a common practice. One JUSMAG officer described the redundancy of effort across agencies as 'phenomenal' while noting that bureaucratic jealousy 'was rampant'-a situation that 'would have frightened any organization-minded intelligence officer' (Valeriano and Bohannan 1962: 138).

The U.S. brought six experienced combat intelligence officers, with prior knowledge of the Philippines, onto the JUSMAG staff to assist the 
$\mathrm{PC}$ and army in developing techniques for cultivating information from friendly civilians and captured insurgents (Memorandum, Hobbs to Joint Chiefs of Staff 1950). JUSMAG also outlined a plan to reorganize intelligence collection for COIN. Implemented in January 1951, this made the MIS the lead agency for COIN intelligence. Intelligence teams were assigned to all the $\mathrm{BCTs}$, decentralizing intelligence collection and dissemination by making the local area commander-rather than a separate intelligence agency or organization-responsible for the intelligence effort in his area of operations (JUSMAG Semi-Annual Report 1951).

To develop a professional intelligence corps, an intelligence school was established which trained 240 officers and 570 enlisted men in the first 18 months of operation (JUSMAG Semi-Annual Report 1952). For the first several years of the conflict, there was no systematic programme for the interrogation of Huk prisoners-captured insurgents were simply locked away and occasionally beaten for information. Under Magsaysay, the maltreatment of prisoners ended, which made them more likely to cooperate and their comrades in the field more likely to surrender. With American guidance, the constabulary built a network of informants and assembled dossiers on known Huks. They also began interrogating the families and friends of insurgents, encouraging them to plead with their loved ones to give up their armed struggle (JUSMAG Semi-Annual Report 1951).

To generate intelligence on the guerrillas while simultaneously delegitimizing them, the government offered extraordinarily large cash bounties for information leading to the capture of Huk leaders. The basic reward began at a rate of 5,000 pesos-10 times the average annual agricultural wage - and went as high as 100,000 for senior Huk commanders (Shalom 1977: 160). Wanted individuals were always portrayed as criminals, with corresponding details provided about the specific robbery, arson, or murder of which they were accused. Publicizing the crimes reduced the insurgents' heroic image while creating divisions between the people and the Huks, as well as between the rank-and-file insurgents and their leadership, who began to worry about the temptations for betrayal such rewards created.

In the early years of the conflict, the security forces had been hamstrung by their lack of reliable information about the insurgents and their organization. This began to change as the combination of better 
treatment of the civilian population and rewards for cooperation paid off in the form of information. Rural inhabitants of Luzon heaped praise on Magsaysay, saying that he 'cleaned up the PC and Philippine army' and 'got rid of the civilian guards'. As one provincial Huk commander noted-'All the reforms that were promised and partially implemented, even though small and show-case in nature, were encouraging for people. Many people believed in the government...' (Quoted in Kerkvilet: 238). Impressed with Magsaysay's sincerity, the Huk commander for greater Manila, Taciano Rizal, approached the Secretary of National Defence with the intention of defecting to the government's side. Rizal provided the government with the location of the insurgents' safe houses in the capital. The simultaneous raid on 22 locations across the city resulted in the arrest of over 100 people, including a large percentage of the politburo as well as 'two truckloads' of the central leaderships' papers (Abueva 1971: 167).

Although the capture of so many senior leaders was a blow for the Huks, the insurgents managed to carry on the fight for several more years. In the months following the capture, they launched daily attacks while expanding their operations into new areas-leading JUSMAG observers to conclude that 'they were not weakened by the capture of the Manila members of their Politburo' (Lansdale 1972: 85-6). Indeed, the Huks themselves judged that the capture of the politburo only resulted in a 'slight lowering of the morale of the ordinary rank-and-file member of the party', while their leadership actually debated expanding the scope of their military operations ('Top Secret Report on Communist Military Committee Conference' 1950).

\section{Resources}

Over the course of the conflict, the weapons and equipment of both the PC and the Philippine army were adjusted to render the forces better suited to conduct discrete COIN operations among a civilian population in a manner that minimized collateral damage. At the same time, a significant effort was undertaken to provide field forces with sufficient provisions to reduce their need to prey on the local civilian population for supplies.

Befitting their paramilitary role, the PC was initially equipped as a light infantry force. Personal weapons consisted of .30 calibre M1 rifles and carbines, supplemented by Browning automatic rifles and .45 calibre 
submachine guns. Fire support came in the form of light and heavy .30 and .50 calibre machine guns, $60 \mathrm{~mm}$ and $81 \mathrm{~mm}$ mortars, and occasionally, batteries of $105 \mathrm{~mm}$ howitzers. Armoured cars and light tanks were employed to maintain security on highways and other major roadways. Following the restructuring of the armed forces, the new constabulary units were stripped of their heavy weapons and armed primarily with .30 calibre rifles and billy clubs-weapons that are more appropriate for police work (Department of the Army 1952: 2).

The constabulary elements that were formed into BCTs also had their armaments altered. Between 1946 and 1950, the PC made frequent use of artillery to shell suspected Huk positions; however, they were rarely successful in bringing major firepower to bear on insurgent bands. Far more often, the local civilian population bore the brunt of this approach, and the resulting casualties not only alienated the populace but also drew the scorn of the insurgents. To facilitate small-unit operations, increase mobility, and reduce collateral damage from COIN operations, the battalion's artillery and heavy mortar sections were replaced with additional rifle companies. Heavy weapons were deployed only in specific scenarios, on an as-needed basis (Valeriano and Bohannan 1962: 133).

For several years, JUSMAG had advised the Philippine government that the 'niggardly attitude' towards the 'pay, clothing and substance allowance' of enlisted men was a major barrier to enhancing the effectiveness of the constabulary and army (Letter, Jones to Quirino 1948). Magsaysay gave emergency status to the procurement and distribution of field rations in order to ensure that government forces were capable of sustaining themselves in the field. This meant that they no longer needed to steal from the population or scavenge supplies when on deployment, leading to a significant improvement in relations with the local peasantry (Valeriano and Bohannan 1962: 208). (In the past, when deployed to the provinces, the underpaid and poorly disciplined members of the constabulary would billet themselves in private homes, appropriate foodstuffs, and force local women to do their cooking and washing (Thorpe 1962: 98).) Magsaysay also used American aid to raise the salary of the armed forces, which further reduced their incentive to rob or extort the population. In 1950, a Filipino soldier did not earn enough even to pay for his daily meals, but Magsaysay tripled wages, both raising their morale and reducing corruption (Greenberg 1987: 85). 


\section{Rule of Law}

The Philippine legal system was designed to protect citizens from capricious and unfair treatment at the hands of the authorities, which posed difficulties for responding to a large-scale insurgency. Since a captured insurgent was entitled to the same due process protections as any other Philippine citizen, a guerrilla was automatically released if they were not presented before a judge within six hours of their arrest and a prima facie case presented against them within 24 hours. Consequently, the constabulary 'found it almost impossible to hold a dissident captive, since the time-space element from the field to the court offices... is frequently greater than six hours' (JUSMAG Semi-Annual Appraisal 1951). Moreover, if the charge filed against the insurgent was anything short of murder, he had a right to demand to be released on bail. As a result, one JUSMAG officer noted-'it was literally true that a Huk, captured in a fire fight could be free and back with his unit within seventy-two hours or less' (Valeriano and Bohannan 1962: 54).

Although they recognized this as a significant problem, politicians from the ruling Liberal Party were unwilling to propose as drastic a step as suspending the writ of habeas corpus, aware that such a move would be deeply unpopular after the brutality of Japanese occupation. More importantly, with a vocal and active press ready to condemn any curtailment of civil liberties and a political opposition looking for any opportunity to attack the government, Liberal Party leaders worried that such an action would devastate their party's electoral chances. The political environment changed following the raid on the politburo in Manila, during which the Philippine government discovered that the insurgents were 'a better organized [and] more potent force than had been imagined' (Lansdale 1972: 63-4). The public revelation of the size and scope of the Huk organization provided the government with the political cover it needed to temporarily suspend the writ of habeas corpus in conflict zones. This move, in turn, enhanced the ability of the government to collect intelligence on the Huks (The Constabulary Story 1982: 302).

\section{Lessons Learned}

Although each insurgency is unique, the experience of the PC suggests several lessons relevant to the deployment of police forces in other 
insurgencies. The first regards the utility of paramilitary police forces in COIN. Bringing the police under the control of the military seems to run counter to the received wisdom of how to employ such forces in COIN, however, the corruption and brutality of the PC made such actions necessary to reform the institution. While some have suggested that paramilitary police forces are well suited for COIN, the experience of the PC in the Huk Rebellion raises doubts. The dual police and military missions were never satisfactorily delineated and the force lacked the training and resources to excel at either mission, let alone both. Although the resources of the Philippine government were particularly scarce in the immediate aftermath of World War II, it did not differ markedly from other countries facing an active insurgency; they often suffer from 'declining public order, rising domestic violence, stagnating economies, and infrastructure deteriorating because of the lack of basic maintenance' (Olson 1993: 11).

Detecting and severing the links between insurgent groups and the civilian supporters they rely on for shelter, transport, and information requires solid investigatory police work. The paramilitary nature of the PC, combined with the limited resources of the Philippine government, prevented that capability from being widely developed among the PC. Furthermore, traditional police forces are believed to be helpful in COIN because they have experience in regularly dealing with civilians as well as achieving their missions using the minimum amount of necessary force, unlike the regular military. That makes them less likely to alienate the public when carrying out internal security duties. In sharp contrast, the paramilitary PC, which did not possess either connections in local society or deep experience in civil policing, responded to the civilian population in Luzon with maximal force. The poor relations that PC units developed with the population in their areas of responsibility hindered the cultivation of the sort of human intelligence networks that police forces can normally provide as a result of their regular interaction with the civilian population. The Philippine government's COIN prospects only improved after the PC's responsibilities for policing and military operations were distributed to separate organizations.

Second, the constabulary experience highlights the critical importance of ensuring adequate pay and logistical support for police forces. As one of the primary points of contact between a government and its population, the police have ample opportunity for corruption. As a result of this 
regular contact, they play a significant role in shaping perceptions of the government, which means major failings in the force can undermine public confidence in the government as a whole. Ensuring sufficient pay and support such that the police do not need to scavenge supplies or extort money from the civilian population must be a priority, as is the establishment of administrative procedures to swiftly dismiss corrupt officers when they are discovered. For a resource-constrained government facing an insurgency, raising police pay may seem like a luxury. However, ultimately it is cheaper to pay to establish a police force made up of high-quality professional officers than it is to undo the damaged inflicted by a repressive and dishonest police force that drives civilians into the arms of the insurgents.

Finally, this episode also suggests that the steps necessary to enhance the effectiveness of the police force (or of COIN operations, more generally) may run directly counter to the interests of the local government. Although the COIN strategies initially adopted by the government were ineffective, its freedom of action was constrained by political considerations. Restructuring of the PC was necessary to enhance its effectiveness, but these very actions challenged the ruling Liberal Party's grip on power. As a result, these changes were bitterly opposed and were only made when the United States linked aid to reform. As expected, the 'loss' of the constabulary cost the Liberal Party first its grip on Congress and later the presidency. A supporting power must be aware that its COIN prescriptions may not be welcomed by the local government and that it may prove necessary to exert significant pressure on an ally to compel reform.

$* * *$

Although subordinating the police to the army when conducting COIN operations is contrary to the advice of most theorists, the Huk Rebellion illustrates that there are no cookie-cutter solutions to insurgency. The extraordinary step of putting the police and the army under a single command proved necessary to end the PC's abusive treatment of the civilian population. Concrete grievances against the security forces and the landlords they served were driving popular support for the Huk insurgents in Luzon. Ending this mistreatment and having the security forces undertake civic action projects, which made a tangible 
improvement in the lot of many rural labourers, helped cultivate the impression that government forces were on the side of the people, not the powerful, which reduced the attractiveness of armed opposition. At the same time, the improvement in the population's perception of the security forces enhanced their ability to cultivate intelligence on the insurgents. This proved to be a key turning point - the effectiveness of government forces was not a product of their firepower, but their ability to find the insurgents. In concert with the decentralization of operations and intelligence collection, this increased the effectiveness of forces in the field and allowed them to adapt to local circumstances. Unlike the earlier large-scale sweep operations which involved significant effort and disruption of the civilian population for little gain, small-unit tactics driven by quality intelligence allowed the security forces to put real pressure on the Huks.

The combination of these factors resulted in a COIN campaign that not only proved to be militarily effective, but also convinced the population that the government was worthy of support, undercut most of the justification for armed violence, and provided real incentives for the insurgents to give up the fight. This latter point is demonstrated by the fact that the number of insurgents who surrendered to the government from $1947-53(15,866)$ was larger than the numbers who were captured $(4,269)$ and killed $(9,695)$ combined. Although the PC were not leading the COIN effort at the end of the Hukbalahap Rebellion, their experience confirms the importance of reorganizing and retraining police forces to reduce corruption and abuse of the population in order to develop the intelligence necessary to detect and neutralize the insurgents and their supporters.

\section{References}

\section{Primary Sources}

Declassified Documents Reference Service, Farmington Hills, MI. Office of Intelligence Research. 1950. Report No. 5209, 'The Hukbalahaps', 27 September 27.

Department of the Army. 1952. 'Philippine Constabulary', Intelligence Research Project, 15 December.

Elpidio R. Quirino Papers, Filipinas Heritage Library, Manila. Letter, Jones to Quirino. 5 May 1948, Box 23. 
Letter, Anderson to Quirino. 14 June 1950, Box 23.

Memorandum, Baluyut to Quirino. 9 March 1949, Box 14.

Memorandum, Samaon Afdal to Chief of Constabulary. 1 April 1949. Box 14.

Memorandum, Perez to Quirino, April 14, 1950, Box 7.

'Top Secret Report on Communist Military Committee Conference', 8 November 1950, Box 17.

Foreign Relations of the United States 1950, vol. VI, East Asia and the Pacific.

Telegram 674, Manila to State. 6 March 1950, p. 1418.

Despatch 432, Manila to State. 7 April 1950, p. 1436.

Foreign Relations of the United States 1951, vol. VI, East Asia and the Pacific.

Telegram 1194, Manila to State, February 15, 1951, pp. 1510-11.

Manuel A. Roxas Papers, University of the Philippines Diliman. Memorandum, Peralta to Roxas. 1946. 'Capability of MPC to Deal with Huk Problem’, 19 August. Series IV, Box 18.

Harry S. Truman Presidential Library, Independence, MO.

President's Secretary's Files

CIA Report ORE 33-50. 1950. 'Current Situation in the Philippines', June 27, p. 9.

Memorandum, Melby to Jessup. 25 August 1949, Box 6, Philippine General File.

John F. Melby Papers.

‘AFP Brief for Melby Mission’, 19 September 1950.

‘Embassy Briefing', Melby Mission, 19 September 1950.

JUSMAG. 1950. Brief for Melby Mission, 18 September 1950.

U.S. Air Force Historical Research Agency, Maxwell, Alabama. Lansdale, Edward G. 1971. Oral History Interview, 25 April. 
U.S. National Archive at College Park, MD.

Records of the U.S. Department of State (RG 59).

Airgram A-160, Manila to State. 31 March 1949. 896.00/3-3149.

Airpouch 307, Manila to State. 15 March 1950. 796.00/3-1550.

—339, April 15, 1952. 796.00/4-1552.

_ 814, Manila to State. 28 June 1950. 796.00/6-2850.

Despatch 366, Manila to State. 9 April 1948. 896.00/4-949.

Letter, Abbey to Cowen. 27 November 1951. Box 1, Office of Philippine Affairs.

Letter, Chapin to Gullion. 20 April 1950. Box 2, Office of Philippine Affairs.

Letter, Locket to Marshall. 15 August 1948. 896.00/8-1548.

Memo, Ely to Allison. 2 February 1949. 896.20/2-249.

Memorandum, O’Neal. 19 February 1948. 896.00/2-948.

Telegram 138, Manila to State. 14 January 1949. 896.00/1-1449.

Telegram 211, Manila to State. 26 July 1950. 796.00/7-2650.

Telegram 220, Manila to State. 27 July 1950. 796.00/7-2750.

Telegram 311, Manila to State. 21 March 1949. 896.00/3-2149.

Telegram 458, Manila to State. 13 April 1950. 796.00/4-1350.

Telegram 492, Manila to State. 17 May 1949. 896.00/5-1749.

Telegram 561, Manila to State. 16 June 1949. 896.00/6-1649.

Telegram 578, Manila to State. 23 February 1950. 796.00/2-2350.

Telegram 1011, Manila to State. 8 April 1950. 796.00/4-850. 
Telegram 1126, Manila to State. 28 April 1949. 896.00/4-2849.

Telegram 1152, Manila to State. 21 April 1950. 869.00.00/4-2150.

Telegram 1794, Manila to State. 19 December 1952. 796.00/12-1952.

Telegram 1862, Manila to State. 24 September 1948. 896.00/9-2848.

Telegram 1953, Manila to State, 5 January 1953. 796.00/1-553.

Telegram 2000, Manila to State, December 4, 1951. 796.00/12-451.

Telegram 2157, Manila to State. 26 January 1951. 796.00/1-2651.

Telegram 2200, Manila to State. 23 January 1953. 796.00/1-2353.

Telegram 2318, Manila to State. 4 January 1952. 796.00/1-452.

Telegram 2694, Manila to State. 11 November 1949. 896.00/11-1149.

Records of the U.S. Joint Chiefs of Staff (RG 218)

Memorandum, Hobbs to Joint Chiefs of Staff. 30 June 1950, Box 48, JCS Geographic Files, 1948-50.

Records of Interservice Agencies (RG 334).

JUSMAG. 1949. 'Weekly Summary of Activities', 4 November.

—. 1949. 'Weekly Summary of Activities', 8 December.

—. 1949. 'Weekly Summary of Activities', 22 December.

— 1950. 'Weekly Summary of Activities', 29 July.

—. 1951. 'Semi-Annual Appraisal, January 18, 1951'.

—. 1951. 'Semi-Annual Report, January 1, 1951-June 30, 1951'.

—. 1952. 'Semi-Annual Report, August 1, 1952'.

Secondary Sources

Abaya, Hernando. 1946. Betrayal in the Philippines. New York: A.A. Wyn. 
Abueva, Jose Veloso. 1971. Ramon Magsaysay. Manila: Solidaridad Pub. House.

Bohannan, Charles. 1962. 'Antiguerrilla Operations', Annals of the American Academy of Political and Social Sciences, 341: 19-29.

Cable, Larry E. 1986. Conflict of Myths: The Development of American Counterinsurgency Doctrine During the Vietnam War. New York: New York University Press.

Crozier, Brian. 1960. The Rebels. Boston: Beacon Press.

Greenberg, Lawrence. 1987. The Hukbalahap Insurrection. Washington, DC: U.S. Army Center of Military History.

Hansen, Annika. 2002. 'Civil-Military Cooperation: The Military, Paramilitaries and Civilian Police in Executive Policing', in Renata Dwan (ed.), Executive Policing: Enforcing the Law in Peace Operations. Oxford: Oxford University Press, pp. 67-84.

Hart, Donn. 1953. 'Magsaysay: Philippine Candidate', Far Eastern Survey, 22(6): $67-70$.

Havron, M. Dean, William Chenault, James Dodson, and A. Terry Rambo. 1969. Constabulary Capabilities for Low-Level Conflict. Washington, DC: Office of Naval Research.

Kerkvliet, B.J. 1977. The Huk Rebellion: A Study of Peasant Revolt in the Philippines. Los Angeles: University of California Press.

Lachica, Eduardo. 1971. The Huks: Philippine Agrarian Society in Revolt. London: Praeger.

Lansdale, Edward G. 1972. In the Midst of Wars: An American's Mission to Southeast Asia. New York: Harper \& Row.

Moore, William. 1971. The Hukbalhap Insurgency, 1948-1954. Carlisle, PA: U.S. Army War College.

Mungie, Timothy. 2010. Indigenous Police Forces in Counterinsurgency. Fort Leavenworth, Kansas: United States Army Command and General Staff College. 
Olson, William J. 1993. 'The New World Disorder', in Max G. Manwaring (ed.), Gray Area Phenomena: Confronting the New World Disorder. Boulder, Co.: Westview Press, pp. 3-32.

Owens, William. 1989. Eye-Deep in Hell: A Memoir of the Liberation of the Philippines. Dallas: SMU Press.

Romulo, C.P. and M.M. Gray. 1957. The Magsaysay Story. New York: Pocket Books.

Scaff, Alvin. 1955. The Philippine Answer to Communism. Stanford: Stanford University Press.

Schmidl, Erwin A. 1998. 'Police Functions in Peace Operations: An Historical Overview', in Robert B. Oakley, Michael J. Dziedzic, and Eliot M. Goldberg (eds), Policing the New World Disorder: Peace Operations and Public Safety. Washington, DC: National Defense University.

Shalom, Stephen. 1977. 'Counter-Insurgency in the Philippines', Journal of Contemporary Asia, 7(2): 153-77.

Smith, Robert. 1958. Philippine Freedom, 1946-1958. New York: Columbia University Press.

Taruc, Luis. 1953. Born of the People. Bombay: People's Publishing House.

- 1967. He Who Rides the Tiger: The Story of an Asian Guerrilla Leader. New York: Praeger.

The Constabulary Story. 1982. Quezon City: Public Information Office.

Thorpe, William. 1962. 'Huk Hunting in the Philippines, 1946-1953', The Airpower Historian, April: 95-100.

Valeriano, Napoleon D. and Charles T.R. Bohannan. 1962. Counter-Guerrilla Operations: The Philippine Experience. London: Pall Mall Press. 